\title{
Farm-Based Measures for Reducing Human and Environmental Health Risks from Chemical Constituents in Wastewater
}

Robert Simmons, Manzoor Qadir and Pay Drechsel

\begin{abstract}
There is a significant imbalance between the number of publications describing potential and actual environmental and health impacts from chemically contaminated wastewater, and reports outlining concrete options to minimize the related risks where conventional wastewater treatment is not available. This gap applies more to inorganic and organic contaminants than excess salts or nutrients. This chapter outlines some of the options available that could be considered in and around the farm, looking at heavy metals, salts, excess nutrients and organic contaminants. The emphasis is placed on low-cost options applicable in developing countries. While such measures can reduce negative impacts to a certain extent, it remains crucial to ensure that hazardous chemicals are replaced in production processes; industrial wastewater is treated at source and/or separated from other wastewater streams used for irrigation purposes; and fertilizer application rates and related possible subsidies adjusted to avoid over-fertilization.
\end{abstract}




\section{INTRODUCTION}

Where irrigation with untreated, partly treated or diluted wastewater cannot be avoided or is otherwise common, negative impacts on irrigated crops, soils and groundwater that can affect human and environmental health are likely (Ayers and Westcot, 1985; Murtaza et al., 2009; Pescod, 1992; Pettygrove and Asano, 1985; WHO, 2006b). Several chapters in this book focus on pathogenic threats, related risk assessments and risk mitigation. This chapter has its focus on non-pathogenic contaminants. As outlined in Chapter 6, aside from organic chemicals, debris and solutes, non-pathogenic components of polluted irrigation water can comprise a range of elements that can be essential plant nutrients, undesirable salts or metals and metalloids in toxic concentrations, depending on their concentration and solubility.

The high concentrations of chemical constituents that need to be addressed in wastewater-irrigated environments can be roughly divided into:

- metals and metalloids, such as cadmium (Cd), chromium (Cr), cobalt (Co), molybdenum (Mo), nickel $(\mathrm{Ni})$, zinc $(\mathrm{Zn})$, lead $(\mathrm{Pb})$, arsenic $(\mathrm{As})$, selenium $(\mathrm{Se})$, mercury $(\mathrm{Hg})$, copper $(\mathrm{Cu})$ and manganese $(\mathrm{Mn})$, among others;

- nutrients such as nitrogen $(\mathrm{N})$, phosphorous $(\mathrm{P})$, potassium $(\mathrm{K})$, calcium $(\mathrm{C})$ and magnesium $(\mathrm{Mg})$, which in high concentrations might suppress other nutrients and/or affect plant growth and aquatic life;

- salts and specific ionic species such as sodium $(\mathrm{Na})$, boron (B) and chloride $(\mathrm{Cl})$;

- persistent organic pollutants (POPs), such as pesticides as well as so-called emerging contaminants, like residual pharmaceuticals, endocrine disruptor compounds and active residues of personal care products.

To avoid potential negative impacts, conventional wastewater-treatment options, which can control the release of most of these contaminants into the environment, remain the key to protecting water quality for beneficial uses including agriculture.

In theory, it could be expected that, with increasing economic development and industrialization, treatment standards, regulations and capacities grow concomitantly, allowing a society at each development stage to deal with its own waste. However, there are many development pathways, and growth in each sector of the economy does not always run in parallel. The so-called emerging economies or markets are a good example of this process. China, India, Pakistan and Mexico are some of the largest countries in this group, but they are also those most often cited for large-scale industrial water pollution and irrigation with highly polluted water (Jiménez and Asano, 2008). Many other low-income countries show, at a smaller scale, similar challenges of emerging industrial sectors or mining activities while institutional, technical and/or regulatory capacities for wastewater treatment 
are not yet in place. The result is a situation in which not only microbiological contaminants, but also industrial effluent, pose a threat to farmers and consumers of wastewater-irrigated food. The related possible environmental and health impacts are described in a range of papers (Abaidoo et al., 2009; Hamilton et al., 2007; Stevens and McLaughlin, 2006) but they are usually brief in answering what could be done where appropriate conventional treatment facilities are missing. This chapter tries to address the gap by outlining some options for non-pathogenic contaminants including salts.

\section{METALS AND METALLOIDS}

All of the potentially toxic metals are naturally present in the environment in trace amounts and are ingested with food, water and air. Human bodies have the ability to deal with these background levels. The World Health Organization (WHO) has established guidelines on allowable consumption of various toxins (WHO, 2006a) and guidance values in irrigation water (WHO, 2006b). Several of these metals and metalloids are of particular concern due to their adverse effects on agricultural productivity as well as environmental and human health. In a review of wastewater use in the Australian horticultural production industry, Hamilton et al. (2005) classified potentially phytotoxic metals in wastewater into four groups based on their retention in soil, translocation in plants, phytotoxicity and potential risk to the food chain (Table 11.1). They categorized Cd, Co, Se and Mo as posing the greatest risk to human and animal health because they may accumulate in crops without damaging them. Indeed, the visible symptoms of toxicity vary from plant to plant, even if they contain elevated concentrations of toxic metals and metalloids (Clemens, 2001). The recent the guidelines of the WHO also consider Cd to be of particular concern because of both high levels of toxicity and bioaccumulation in crops (WHO, 2006b).

Metals such as $\mathrm{Cd}, \mathrm{Hg}$ and $\mathrm{Pb}$ do not have any essential function but they are detrimental, even in small quantities, to plants, animals and humans, and accumulate because of their long biological half-life (Goethberg et al., 2002). Other metals and metalloids, such as $\mathrm{Mn}, \mathrm{Zn}, \mathrm{B}$ and $\mathrm{Cu}$ are essential micronutrients in small concentrations, but harmful to crops in higher concentrations. Some, such as $\mathrm{Cu}$ and $\mathrm{Zn}$, become toxic to plants before they reach high enough concentrations to be toxic to humans, thus plants function here as a barrier mitigating potential health risks (Hamilton et al., 2005; Johnson, 2006).

Although wastewater treatment is the best choice in managing wastewater in agriculture, the costs involved in engineering-based technologies for wastewater treatment are prohibitively high for most developing countries. Even where wastewater treatment plants are externally funded, they usually only treat a small fraction of the wastewater produced and, depending on their type, can face significant maintenance problems. However, some farm-based measures and low- 
Table 11.1 Metal bio-availability grouping

\begin{tabular}{|c|c|c|c|c|}
\hline Group & Metal & Soil adsorption & Phytotoxicity & Food chain risk \\
\hline 1 & $\begin{array}{l}\mathrm{Ag}, \mathrm{Cr}, \mathrm{Sn} \\
\mathrm{Ti}, \mathrm{Y} \text { and } \mathrm{Zr}\end{array}$ & $\begin{array}{l}\text { Low solubility } \\
\text { and strong } \\
\text { retention in soil }\end{array}$ & Low & $\begin{array}{l}\text { Little risk because they } \\
\text { are not taken up to any } \\
\text { extent by plants }\end{array}$ \\
\hline 2 & $\begin{array}{l}\mathrm{As}, \mathrm{Hg} \text { and } \\
\mathrm{Pb}\end{array}$ & $\begin{array}{l}\text { Strongly } \\
\text { sorbed by soil } \\
\text { colloids }\end{array}$ & $\begin{array}{l}\text { Plant roots may adsorb } \\
\text { them but not translocate } \\
\text { to shoots; generally not } \\
\text { phytotoxic except at very } \\
\text { high concentrations }\end{array}$ & $\begin{array}{l}\text { Pose minimal risks to } \\
\text { the human food chain }\end{array}$ \\
\hline 3 & $\begin{array}{l}\mathrm{B}, \mathrm{Cu}, \mathrm{Mn}, \\
\mathrm{Mo}, \mathrm{Ni} \text { and } \\
\mathrm{Zn}\end{array}$ & $\begin{array}{l}\text { Less strongly } \\
\text { sorbed by soil } \\
\text { than Groups } \\
1 \& 2\end{array}$ & $\begin{array}{l}\text { Readily taken up by } \\
\text { plants and phytotoxic at } \\
\text { concentrations that pose } \\
\text { little risk to human health }\end{array}$ & $\begin{array}{l}\text { Conceptually the } \\
\text { 'soil-plant barrier' } \\
\text { protects the food chain } \\
\text { from these elements }\end{array}$ \\
\hline 4 & $\begin{array}{l}\text { Cd, Co, Mo } \\
\text { and Se }\end{array}$ & $\begin{array}{l}\text { Least of all } \\
\text { metals }\end{array}$ & $\begin{array}{l}\text { Pose human and/or animal } \\
\text { health risks at plant tissue } \\
\text { concentrations that are not } \\
\text { generally phytotoxic }\end{array}$ & $\begin{array}{l}\text { Bioaccumulation } \\
\text { through the soil-plant- } \\
\text { animal food chain }\end{array}$ \\
\hline
\end{tabular}

Source: From Hamilton et al. (2005)

cost treatment options can reduce the risk to the environment and human health (WHO, 2006b).

The key steps to follow are:

- identifying which geographical areas have elevated risk based on consideration of potential metal sources;

- quality-assured testing of soil and plant samples to verify the level of risk;

- identifying alternative varieties of the same desired crop that take up the least metal or convert the toxin to less toxic forms when grown in high-risk areas;

- developing irrigation, fertilization and residue management strategies that help to minimize metal uptake by plants;

- recommending cultivation of other crops with lower health risk (crop restrictions) if the measures mentioned above fail to safeguard humans;

- zoning affected areas for non-agricultural land use or land rehabilitation.

Most knowledge refers to the last option and industrially contaminated sites in developed countries where the affected land has a high value and costs of remediation are met by the state or by the polluter. In these cases, in situ and ex situ engineering options are applied (Table 11.2).

However, within the economic constraints of developing countries and in terms of farm-based strategies aimed at addressing wastewater-induced contamination of $\mathrm{metal} / \mathrm{metalloids,} \mathrm{viable} \mathrm{risk-reduction} \mathrm{options} \mathrm{can} \mathrm{be} \mathrm{categorized} \mathrm{as:}$ 
Table 11.2 In situ and ex situ engineering options adopted for remediated metal/metalloid contaminated soils

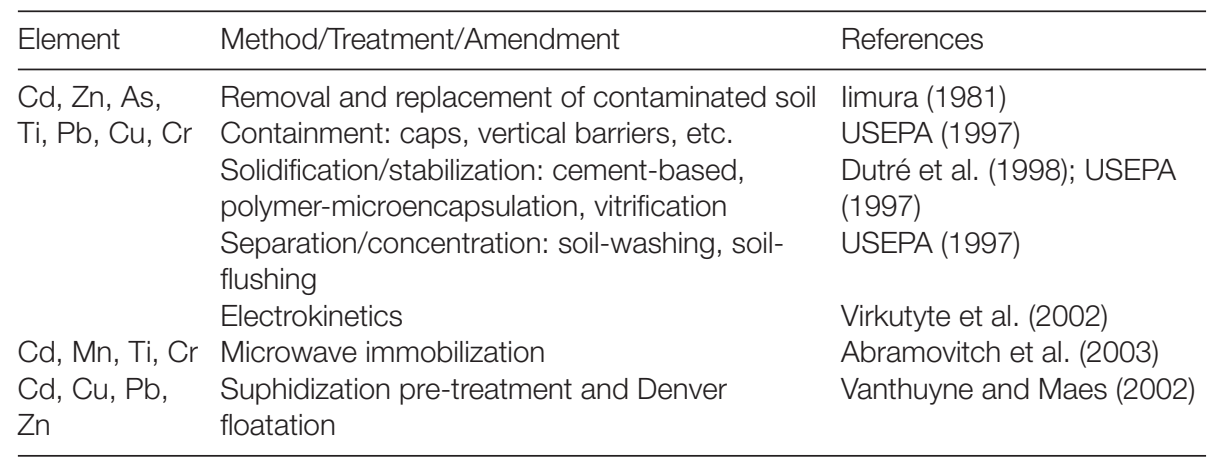

- Soil-based treatment with non-toxic amendments to form insoluble complexes of metals and metalloids, rendering their availability at low concentrations in the root zone.

- Plant-based strategies for soils and waters contaminated with metals and metalloids through the cultivation of specific plant species capable of accumulating target ionic species in their shoots, thereby removing them from the soil or water. These mechanisms include phytoremediation (including hyperaccumulation and phytomining), chelate-enhanced phytoextraction and the use of transgenic crops.

\section{Soil-based treatment}

Hamilton et al. (2007) describe increasing total heavy metal concentrations in soils irrigated with sewage for up to a century. The authors also found that potentially bio-available forms of the metals have increased. However, the authors also report that plant tissue showed relatively low concentrations as the metals were strongly absorbed in the soil. Steering the processes that limit the solubility and plant availability of heavy metals and metalloids in soils is possible, e.g. through the use of soil amendments including gypsum, lime $\left(\mathrm{CaCO}_{3}\right)$, phosphate materials, hydrous $\mathrm{Fe}$ and $\mathrm{Mn}$ oxides, clay minerals and organic matter (Table 11.3).

These amendments have been shown to immobilize metals and metalloids through:

- formation of insoluble metal phosphate minerals;

- sorption of contaminants on Fe and Mn oxide surface-exchange sites, co-precipitation - formation of contaminant Fe and Mn compounds;

- sorption of contaminants on exchange sites of organic materials including manures, composts and sludges; 
Table 11.3 Soil amendments utilized for the in situ immobilization of metals and metalloids

\begin{tabular}{|c|c|c|}
\hline Element & Method/Treatment/Amendment & References \\
\hline $\mathrm{Pb}$ & Hydroxyapatite (HA) & $\begin{array}{l}\text { Chlopecka and Adriano (1997); } \\
\text { Zhu et al. (2004) }\end{array}$ \\
\hline $\mathrm{Cd}$ & $\begin{array}{l}\text { Alkaline biosolids, lime-stabilized } \\
\text { biosolids }\end{array}$ & Basta et al. (2001); Wong et al. (2004) \\
\hline $\mathrm{Cd} / \mathrm{Zn}$ & Sepiolite & $\begin{array}{l}\text { Alvarez-Ayuso and García-Sánchez } \\
\text { (2003) }\end{array}$ \\
\hline $\begin{array}{l}\mathrm{Ti}, \mathrm{Zn}, \mathrm{Cd}, \mathrm{Mn} \text {, } \\
\mathrm{Pb}, \mathrm{Hg} \text { and } \mathrm{Co}\end{array}$ & Zeolite (natural and synthetic) & $\begin{array}{l}\text { Chlopecka and Adriano (1997); } \\
\text { García-Sánchez et al. (1999); } \\
\text { Haidouti (1997); Malliou et al. (1994); } \\
\text { Oste et al. (2002) }\end{array}$ \\
\hline $\mathrm{Pb}$ & $\begin{array}{l}\text { Phosphoric acid }\left(\mathrm{H}_{3} \mathrm{PO}_{4}\right) \text { and } \\
\text { calcium dihydrogen phosphate } \\
\left(\mathrm{Ca}\left(\mathrm{H}_{2} \mathrm{PO}_{4}\right)_{2}\right)\end{array}$ & $\begin{array}{l}\text { Brown et al. (2004); Chen et al. } \\
\text { (2003); Melamed et al. (2003) }\end{array}$ \\
\hline $\mathrm{Cd}$ and $\mathrm{Pb}$ & Iron oxide waste by-product & Chlopecka and Adriano (1997) \\
\hline $\mathrm{Cd}, \mathrm{Pb}$ and $\mathrm{Zn}$ & Di-ammonium phosphate (DAP) & McGowen et al. (2001) \\
\hline $\mathrm{Pb}$ & Phosphate rock & $\begin{array}{l}\text { Basta et al. (2001); Hettiarachchi et } \\
\text { al. (2001) }\end{array}$ \\
\hline $\mathrm{Pb}, \mathrm{Cd}, \mathrm{Zn}$ & Triple super phosphate (TSP) & $\begin{array}{l}\text { Hettiarachchi et al. (2001); } \\
\text { Hettiarachchi and Pierzynski (2002) }\end{array}$ \\
\hline $\mathrm{Cd}, \mathrm{Pb}$ and $\mathrm{Zn}$ & Phosphate clay & Singh et al. (2001) \\
\hline $\mathrm{Pb}$ & Mn oxide & Hettiarachchi and Pierzynski (2002) \\
\hline $\mathrm{Cd}$ & Liming & McLaughlin and Singh (1999) \\
\hline $\begin{array}{l}\mathrm{Cr}(\mathrm{Cr}(\mathrm{VI}) \\
\text { reduction to } \\
\mathrm{Cr}(\mathrm{III}))\end{array}$ & Organic amendments & Bolan et al. (2003) \\
\hline $\mathrm{Ni}$ & Limestone & Kukier and Chaney (2001) \\
\hline As & $\begin{array}{l}\text { Simultaneous addition of lime and } \\
\mathrm{FeSO}_{4}\end{array}$ & $\begin{array}{l}\text { Warren et al. (2003); Warren and } \\
\text { Alloway (2003) }\end{array}$ \\
\hline As & Goethite & Garcia-Sànchez et al. (1999) \\
\hline As & $\begin{array}{l}\text { Water treatment sludges and red } \\
\text { mud }\end{array}$ & Lombi et al. (2004) \\
\hline
\end{tabular}

- sorption of contaminants on mineral surface-exchange sites or incorporation into the mineral structure of zeolites, natural aluminosilicates and aluminosilicate by-products.

The aforementioned amendments form insoluble complexes of metals and metalloids, reducing their availability at low concentrations in the root zone and reducing their assimilation by plants (Hussain, 2000; Zhu and Alva, 1993).

Although soil-based management via addition of amendments to immobilize metals/metalloids offers great opportunity to minimize element bio-availability, practical limitations must be considered. These include the management of sites co-contaminated with several elements; cost and availability of amendments; cost 
of long-term monitoring programmes; and suitability to particular soil and climatic conditions. Care should also be taken in the post-management phase, particularly if the site is exposed to acidic water (low $\mathrm{pH}$ ) which may transform insoluble complexes into soluble forms.

\section{Plant-based treatments}

Soils contaminated with metals and metalloids can be improved through the use of certain plant species. This approach is broadly known as phytoremediation (Chaney et al., 2007; Cunningham et al., 1995; Salt et al., 1996). As an important category of phytoremediation, phytoextraction involves the use of pollutantscavenging plants to absorb and concentrate metals and metalloids from the soil into above-ground biomass, which may be harvested to remove the elements from the field (Table 11.4). Plants able to accumulate high concentrations of metals are known as hyperaccumulators (Box 11.1).

\section{BOX 11.1 HyPERACCUMULATORS}

Three internationally recognized hyperaccumulator definitions are used to describe the efficiency of phytoextraction for a given metal or metalloid, namely:

- Translocation Factor;

- Extraction Coefficient;

- Bioaccumulation Factor.

The Translocation Factor or shoot/root quotient is defined as the ratio of a given heavy metal in plant shoots as compared with that in the plant root. A Translocation Factor $>1.0$ indicates preferential partitioning of metals to the shoot (Baker and Whiting, 2002; Branquinho et al., 2007; González and González-Chávez, 2006). The Extraction Coefficient has been described as the heavy metal concentration in the shoot divided by the (total) heavy metal concentration in soil and can be used to evaluate the ability of a plant to accumulate a heavy metal (Branquinho et al., 2007; Chen et al., 2004). Finally, the Bioaccumulation Factor is defined as the ratio of metal concentration in plant shoots to the extractable concentration of metal in the soil and is used for the quantitative expression of accumulation (Branquinho et al., 2007; Derem et al., 2006).

The concentrations of metals accumulated in hyperaccumulator plants may be 100 times greater than those occurring in non-accumulator plants growing on the same substrates (Chaney et al., 2007). Currently, there are more than 400 plant species categorized as hyperaccumulators of metals and metalloids (Cobbett, 2003). 
Table 11.4 Selected case studies on phytoremediation

\begin{tabular}{|c|c|c|}
\hline Element & Plant Species & Reference \\
\hline As & $\begin{array}{l}\text { Pteris vittata L. and Pityrogramma } \\
\text { calomelanos }\end{array}$ & $\begin{array}{l}\text { Francesconi et al. (2002); Tu and Ma (2002); } \\
\text { Wongkongkatep et al. (2003); Zhang et al. } \\
\text { (2002) }\end{array}$ \\
\hline $\mathrm{Cd} / \mathrm{Zn}$ & Thlaspi caerulescens & $\begin{array}{l}\text { Brown et al. (1994, 1995a, 1995b); Lombi et } \\
\text { al. (2001); Schwartz et al. (2003) }\end{array}$ \\
\hline $\mathrm{Ni}$ & $\begin{array}{l}\text { Alyssum murale, Phyllanthus } \\
\text { serpentinus, Berkheya coddii }\end{array}$ & $\begin{array}{l}\text { Abou-Shanab et al. (2003); Chaney et al. } \\
\text { (2007); Kersten et al. (1979); Robinson et al. } \\
\text { (1999) }\end{array}$ \\
\hline Se & Astragalus racemosus & Parker et al. (1991) \\
\hline $\mathrm{Mn}$ & $\begin{array}{l}\text { Alyxia rubricaulis, Phytolacca } \\
\text { acinosa Roxb. }\end{array}$ & Brooks et al. (1981); Xue et al. (2004) \\
\hline $\mathrm{Ti}$ & $\begin{array}{l}\text { Biscutella laevigata, Iberis } \\
\text { intermedia }\end{array}$ & Anderson et al. (1999) \\
\hline $\mathrm{Cu}$ & $\begin{array}{l}\text { Aelanthus biformifolius, } \\
\text { Haumaniastrum katangense }\end{array}$ & Brooks (1977); Brooks et al. (1978) \\
\hline Co & Haumaniastrum robertii & Brooks et al. (1978) \\
\hline
\end{tabular}

Because the costs of growing a phytoremediation crop are minimal as compared to those of soil removal and replacement, the use of plants to remediate hazardous soils is seen as having great promise (Chaney et al., 2007). This is particularly pertinent for elements that may provide economic phytomining potential $(\mathrm{Ni}$, $\mathrm{Co}, \mathrm{Ti}$ and $\mathrm{Au}$ ). Following harvest of the metal-enriched plants, their weight and volume can be reduced by burning the dried biomass which results in a high-grade 'metal ore'.

Chelate-enhanced phytoextraction utilizing ethylenediaminetetraacetic acid (EDTA) and high biomass producing plant species such as Brassica juncea (L.) Czern (Indian mustard) has also been investigated (Kumar et al., 1995). However, an observed drawback was the equally enhanced leaching of $\mathrm{Pb}$ down the soil profile (Greman et al., 2003; Madrid et al., 2003; Römkens et al., 2001; Wu et al., 2004).

In addition to phytoextraction, phytoremediation can also be achieved through reduction in the bio-availability of metals in the soil (phytostabilization), volatilization of pollutants such as $\mathrm{Hg}$ and Se from the foliage (phytovolatilization) and removal of contaminants by plant roots from flowing water (rhizofiltration) (Pilon-Smits, 2005). Rhizofiltration is particularly effective in applications where low metal concentrations and large volumes of water are involved (Salt et al., 1996).

However, phytoremediation has certain limitations which need to be addressed in general and on a site- and contaminant-specific basis. These include: 
- Phytoextraction of metals and metalloids may take years/decades which limits its practical applicability.

- It is restricted to sites where the concentration of the contaminants (or cocontaminants) are not toxic to the plants proposed for phytoremediation.

- A specific phytoremediation 'prescription' cannot be applied to every site with a certain chemical contaminant because different site-specific conditions may not be suitable for the target plant.

- In situ phytoremediation is often restricted to sites conducive to growth of the selected plant with the contaminant located within the root zone.

- It is limited by bio-availability of pollutants, only a fraction of which may be bio-available but regulatory clean-up standards require that all the pollutant is removed. In this scenario phytoremediation may not be applicable.

\section{Crop choice and crop restriction}

As described above, crops vary in their absorption behaviour and thus risk potential for humans. In addition, some crops are consumed in larger quantities than others and some are only used as fodder plants and might not enter the human food chain. Thus, crop selection can contribute to decreasing human health risks. For example, in the case of irrigation with untreated wastewater, leafy vegetables accumulate certain metals such as Cd in greater amounts than non-leafy species (Qadir et al., 2000). Bellows (1999) gives as a rule of thumb a heavy metal absorption ratio of 1:10 for fruits and seeds versus leaves and roots. This favours cereals, legumes like beans and peas, tomatoes or fruits over vegetables such as lettuce, cauliflower, carrots or spinach. However, consideration must be given to the quantities of e. $\mathrm{g}$. rice or leafy vegetables actually consumed, and hence contribution to dietary intake of the metal or metalloid, before farmers are challenged to change their cropping pattern. There is a strong relationship between the long term consumption of Cd-contaminated rice and human Cd disease (Kobayashi et al., 2002; Nordberg, 2003).

A shift in crop choice is only feasible and sustainable if there is a market and comparative market value for the alternative crop, unless subsidies are provided. Changed cropping practices might also require additional training and different tools, or even long-term tenure security if, for example, tree crops are recommended. Crop restrictions can therefore be hard to implement if necessary conditions are not in place. There are, however, examples of successful or partly successful implementation of crop restriction in wastewater use schemes in several countries such as India, Mexico, Peru, Chile, Jordan and Syria (Blumenthal et al., 2000; Qadir et al., 2007b). However, the probability of success appears much lower in sub-Saharan Africa and other countries where wastewater irrigation is not confined to (regulated) irrigation schemes but takes place along polluted streams and thus remains informal. 


\section{Zoning}

Where there are no further options to maintain the farm, the affected areas might have to be mapped and taken out of production. Simmons et al. (2009) developed a General Linear Regression Model to predict the spatial distribution of soil Cd in a $\mathrm{Cd} / \mathrm{Zn}$ co-contaminated cascading irrigated rice-based system in Thailand. Preliminary validation indicated that the model can predict soil $\mathrm{Cd}$ based on minimal soil sampling and the field's proximity to primary outlets from in-field irrigation channels and subsequent inter-field irrigation flows. Previous research (Simmons et al., 2005) and subsequent health studies confirming Cd-induced renal dysfunction in the exposed population (Swaddiwudhipong et al., 2007; Teeyakasem et al., 2007) also demonstrated the validity of assessing health risks through monitoring Cd intake via dietary exposed pathways in comparison to the Joint FAO/WHO Expert Committee on Food Additives (JECFA) Provisional Tolerable Weekly Intake values established for $\mathrm{Cd}$. While $\mathrm{Cd}$ is of high risk, as stated above, soil sampling alone might not be a sufficient indicator of the actual health risk. This is reiterated in the example of arsenic (Box 11.2). However, zoning and taking contaminated areas out of food production should be accompanied by adequate compensation for farmers /landowners or alternative income-generating livelihood opportunities, associated with training and assured markets or subsidies.

\section{BOX 11.2 THE CASE OF ARSENIC}

Sources of arsenic contamination in rice fields include geologic soil materials that are naturally high in arsenic; irrigation with contaminated groundwater; residual arsenical pesticides; or application of poultry manure from chickens treated with arsenical antiparasite food additives. In Bangladesh, which has widespread geologic arsenic contamination, the many documented cases of arsenic poisoning have been caused by consumption of contaminated drinking water, not food, although arsenic is of more concern in rice than in other grain crops because flooded soil conditions make arsenate, which mimics the plant nutrient phosphate, more available to plants. However, far more arsenic accumulates in leaves than in grain and, according to Johnson (2006), experiments have so far failed to measure arsenic concentrations above published safe limits in rice grain, even in very contaminated soil. This situation may have changed. Williams et al. (2006) predicted that a daily consumption of rice in Bangladesh with a common total arsenic level of $0.08 \mu \mathrm{g} \mathrm{As} \mathrm{g}^{-1}$ is similar to a drinking-water intake with the allowed arsenic concentration of $10 \mu \mathrm{g}$ per litre. Meharg et al. (2008) reported that inorganic arsenic is in particular elevated in the bran layer of unpolished (brown) rice and less in white rice. According to $\mathrm{FAO}$, planting rice in raised beds around $15 \mathrm{~cm}$ above the ground and not in conventional flooded fields counteracted yield losses and resulted in lower arsenic levels in crops and in the soil, as a pilot field study in Bangladesh revealed (Duxbury et al., 2007). 


\section{NUTRIENTS IN EXCESS}

Wastewater usually contains valuable plant nutrients, such as N, P and K. Depending on whether raw or diluted wastewater is used, the concentrations of the nutrients can vary significantly and might reach levels that can replace fertilizers or are in excess of crop needs and, if biased to certain nutrients, might affect others. Although availability of these nutrients is considered to be a driving force for wastewater irrigation in some developing countries, managing appropriate levels of nutrients in wastewater is a challenging task. Related studies usually encounter a variety of challenges which reduce the management options for farmers.

In general, nutrients in irrigation water are immediately available to the crop, as long as they remain dissolved in the water and soil solution, but may be rendered less available by several soil processes. Some processes result in permanent loss (leaching, volatilization and erosion) and others in nutrient accumulation in the soil (microbiological immobilization, adsorption and precipitation). Hence the proportions of nutrients taken up by plants are different from the proportions of nutrients applied via wastewater (or fertilizers). Because soils and wastewater seldom contain nutrients in optimum ratios, guidelines are needed to optimize wastewater irrigation. A related concept has been presented by Janssen et al. (2005). It requires, however, information on nutrient levels in water, soils and plants, which may not be readily available to resource-poor wastewater farmers or relevant government departments unless obtained through site-specific field trials.

To avoid excessive or unbalanced additions of particular nutrients to wastewaterirrigated soils and crops, farmers can select crops which are less sensitive to high nutrient levels or which can take advantage of high amounts of $\mathrm{P}$ and $\mathrm{N}$. Higher $\mathrm{N}$-levels are thus more welcome in farms specializing in leafy vegetables than grains. In addition, fodder grass is well suited to wastewater-irrigation and acts as a scavenger for $\mathrm{N}$ and $\mathrm{P}$ applied via wastewater. Reduction efficiencies of 84 per cent for $\mathrm{N}$ and 54 per cent for $\mathrm{P}$ have been reported from wastewater irrigated pastures in Zimbabwe (Nhapi et al., 2002). However, land- and soil-based options depend not only on the type of crop but also local soil and site conditions. Medium- to fine-textured soils, for example, may hold more nutrients than sandy soils, thereby releasing lower quantities in the water percolating through the soil and adding to the groundwater. Groundwater-quality monitoring is required where groundwater is shallow and used for drinking purposes.

Where farmers do not have the option to grow crops which benefit from high $\mathrm{N}$ or P levels, the irrigation water might first pass through other systems to transform part of its nutrient load into biomass. This could be an on-farm pond covered with duckweed or a wetland system, like the traditional tank cascades found in Sri Lanka (Awuah et al., 2004; Mahatantila et al., 2008; Nhapi, 2004). In all of these cases, however, it is necessary to remove the net biomass growth in order to prevent eventual decay of the biomass and re-release of the nutrients (Strom, 2006). 
Observations from larger urban settings in developed countries show that effluent treatment by land application for cropping and forestry is often less economical than other treatment techniques. This might be due to the increasing economic land value near cities, but in particular the need in temperate climates to cater for the cold season when soils might be sealed by ice, with plants not growing or in dormant state (Jayawardane et al., 2001). In addition, where soils have restricted internal drainage capacity, soil degradation can occur through waterlogging and salinization (Jayawardane et al., 2001; Su et al., 2005). Hence most land-disposal processes are dependent on freely draining soils and the existence of some diversion structure to store effluent during periods of low absorption capacity or plant water demand.

To overcome the constraints associated with conventional land disposal of wastewater in Australia, the Filtration and Irrigated Cropping for Land Treatment and Effluent Reuse (FILTER) technique was developed for the treatment and reuse of secondary sewage effluent (Gardner et al., 2001; Jayawardane, 1995). The FILTER technique combines the use of nutrient-rich wastewater for intensive cropping with biological and physio-chemical filtration through the soil to a subsurface drainage system. It was initially tested on eight 1-ha experimental plots and subsequently trialled on four (4-ha) commercial-scale plots. FILTER plots were constructed by deep ripping to around $1 \mathrm{~m}$ depth and installing the subsurface drainage system at this depth. The sewage effluent was applied as flood irrigation at the top end of the FILTER plots. Besides nutrient removal, other beneficial effects were reduced suspended solids, oil and grease, and an increased N/P ratio in the drainage water (Blackwell and Arakel, 2004). An obvious disadvantage is the cost factor and equipment required for the set-up of the system, even at smaller scale. However, there might be options for low-cost adaptations.

In cases where there are excess nutrient levels such as $\mathrm{N}$ or salts (see below), wastewater can be diluted with freshwater, where possible, to decrease the nutrient concentration and increase the benefits through a higher volume of irrigation water. This option might have a strong seasonal dimension and is only possible where wastewater streams are separated from other surface-water bodies. Where freshwater is not available, the quantity of wastewater applied per unit area can be decreased. The same applies to wastewater with high levels of organic matter. In this case, wastewater should not be applied continuously to allow soil to biodegrade organic matter.

\section{SALTS AND SPECIFIC IONIC SPECIES}

Wastewater contains more soluble salts than freshwater because salts are added to it from different sources (Qadir et al., 2007b). There are no economically viable means to remove the salts once they enter wastewater because the techniques, such as cation exchange resins or reverse-osmosis membranes, are prohibitively expensive and are only used to produce high-quality recycled water (Toze, 2006a). 
For remediation purposes, wastewater can be divided into: saline wastewater containing excess levels of soluble salts; sodic wastewater characterized by excess levels of sodium $\left(\mathrm{Na}^{+}\right)$; and saline-sodic wastewater having both salts and $\mathrm{Na}^{+}$in excess concentrations.

The last category is most prevalent. Salinity in wastewater is characterized by its electrical conductivity (EC) expressed in terms of deci-Siemens per metre (dS $\mathrm{m}^{-1}$ ). Sodicity is assessed by sodium adsorption ratio (SAR), which is expressed as the relative amounts of $\mathrm{Na}^{+}$to that of divalent cations, calcium $\left(\mathrm{Ca}^{2+}\right)$ and magnesium $\left(\mathrm{Mg}^{2+}\right)$.

For long-term irrigation with saline and/or sodic wastewater, there is a need for site-specific preventive measures and management strategies, which may include:

- appropriate selection of crop or crop variety capable of producing profitable yield with saline wastewater;

- selection of irrigation methods to reduce crop exposure;

- application of wastewater in excess of crop water requirement (evapotranspiration) to leach excess salts from the root zone;

- wastewater irrigation in conjunction with freshwater, if available, through cyclic applications and/or blending;

- in the case of salt-sensitive crops, via careful seedbed preparation and planting techniques;

- in the case of highly sodic wastewater, through the application of $\mathrm{Ca}^{2+}$ (e.g. via gypsum or alternative calcium-rich wastewater) to mitigate $\mathrm{Na}^{+}$effects on soils and crops.

\section{Crop selection and diversification}

Research efforts have led to the identification of a number of field crops, forage grasses and shrubs, biofuel crops, fruit trees and agroforestry systems which can suit a variety of salt-affected environments and local or regional markets (Maas and Grattan, 1999; Qadir et al., 2008). Salt tolerance depends on several soil, crop and climatic factors and is generally divided into four classes: sensitive; moderately sensitive; moderately tolerant; and tolerant. Relative salt tolerance threshold values for a range of crops as a function of average root-zone salinity are given in Table 11.5. Absolute tolerances will, however, vary depending on climate, soil conditions and cultural practices.

The genetic diversity among these crops provides a range of cropping options, especially as salinity tolerance often varies between different varieties of the same crop. For some crops particular salt-tolerant varieties have been created. Local extension officers and crop-research institutes will be able to provide advice on their in- and output markets. 
Table 11.5 Yield potentials of some grain, forage, vegetable and fibre crops as a function of average root-zone salinity

\begin{tabular}{llccc}
\hline Common name & Botanical name & \multicolumn{3}{c}{$\begin{array}{c}\text { Yield potential (\%) at specified salinity } \\
\left(\mathrm{dS} \mathrm{m}^{-1}\right)\end{array}$} \\
\cline { 3 - 5 } & & $50 \%$ & $80 \%$ & $100 \%$ \\
\hline Durum wheat & Triticum durum Desf. & 19 & 11 & 6 \\
Barley & Hordeum vulgare L. & 18 & 12 & 8 \\
Cotton & Gossypium hirsutum L. & 17 & 12 & 8 \\
Rye & Secale cereale L. & 16 & 13 & 11 \\
Sugar beet & Beta vulgaris L. & 16 & 10 & 7 \\
Wheat & Triticum aestivum L. & 13 & 9 & 6 \\
Purslane & Portulaca oleracea L. & 11 & 8 & 6 \\
Sorghum & Sorghum bicolor (L.) Moench & 10 & 8 & 7 \\
Alfalfa & Medicago sativa L. & 9 & 5 & 2 \\
Spinach & Spinacia oleracea L. & 9 & 5 & 2 \\
Broccoli & Brassica oleracea L. & 8 & 5 & 3 \\
Egg plant & Solanum melongena L. & 8 & 4 & 1 \\
Rice & Oryza sativa L. & 7 & 5 & 3 \\
Potato & Solanum tuberosum L. & 7 & 4 & 2 \\
Maize & Zea mays L. & 6 & 3 & 2 \\
Carrot & Daucus carota L. & 6 & 3 & 1 \\
\hline
\end{tabular}

Source: Based on the salt-tolerance data of different crops and percentage decrease in yield per unit increase in root-zone salinity in terms of $\mathrm{dS} \mathrm{m}^{-1}$ as reported by Maas and Grattan (1999)

Crop-diversification systems based on salt-tolerant plant species are likely to be the key to future agricultural and economic growth in regions where saline wastewater is used for irrigation. Such systems, linked to secure markets, should support farmers in finding the most suitable and sustainable crop-diversifying systems to mitigate any perceived production risks, while ideally also enhancing the productivity per unit of saline wastewater and protecting the environment. In all cases, farmers are encouraged to test the actual performance of suggested varieties on their fields.

\section{Irrigation method}

There are different ways to irrigate crops, such as surface or flood irrigation, manual irrigation with watering cans, furrow irrigation, sprinkler irrigation and microirrigation such as drip or trickle irrigation. Some are more suitable for saline water or other types of low-quality water than others. The clogging of drip irrigation systems is an example. Another one is sprinkler irrigation which may cause injury to crops from the sodium and chloride salts absorbed directly through wetted leaf surfaces, especially where climatic conditions favour evaporation (Ayers and Westcot, 1985). Several factors affect salt accumulation in leaves: leaf age, shape, 
Table 11.6 Parameters for evaluation of commonly used irrigation methods in relation to risk reduction

\begin{tabular}{|c|c|c|c|c|}
\hline \multirow{2}{*}{$\begin{array}{l}\text { Evaluation } \\
\text { parameter }\end{array}$} & \multicolumn{4}{|c|}{ Irrigation method } \\
\hline & Furrow irrigation & Border irrigation & Sprinkler irrigation & Drip irrigation \\
\hline $\begin{array}{l}\text { Foliar wetting and } \\
\text { consequent leaf } \\
\text { damage resulting } \\
\text { in poor yield }\end{array}$ & $\begin{array}{l}\text { No foliar injury } \\
\text { as the crop is } \\
\text { planted on the } \\
\text { ridge }\end{array}$ & $\begin{array}{l}\text { Some bottom } \\
\text { leaves may be } \\
\text { affected but the } \\
\text { damage is not } \\
\text { so serious as to } \\
\text { reduce yield }\end{array}$ & $\begin{array}{l}\text { Severe leaf } \\
\text { damage can } \\
\text { occur resulting in } \\
\text { significant yield } \\
\text { loss }\end{array}$ & $\begin{array}{l}\text { No foliar injury } \\
\text { occurs under } \\
\text { this method of } \\
\text { irrigation }\end{array}$ \\
\hline $\begin{array}{l}\text { Root zone salt } \\
\text { accumulation } \\
\text { with repeated } \\
\text { applications }\end{array}$ & $\begin{array}{l}\text { Salts tend to } \\
\text { accumulate in } \\
\text { the ridge which } \\
\text { could harm the } \\
\text { crop }\end{array}$ & $\begin{array}{l}\text { Salts move } \\
\text { vertically } \\
\text { downwards and } \\
\text { are not likely to } \\
\text { accumulate in } \\
\text { the root zone }\end{array}$ & $\begin{array}{l}\text { Salt movement } \\
\text { is downwards } \\
\text { and root zone } \\
\text { is not likely to } \\
\text { accumulate salts }\end{array}$ & $\begin{array}{l}\text { Salt movement is } \\
\text { radial along the } \\
\text { direction of water } \\
\text { movement. A salt } \\
\text { wedge is formed } \\
\text { between drip } \\
\text { points }\end{array}$ \\
\hline $\begin{array}{l}\text { Ability to maintain } \\
\text { high soil water } \\
\text { potential }\end{array}$ & $\begin{array}{l}\text { Plants may } \\
\text { be subject to } \\
\text { stress between } \\
\text { irrigations }\end{array}$ & $\begin{array}{l}\text { Plants may be } \\
\text { subject to water } \\
\text { stress between } \\
\text { irrigations }\end{array}$ & $\begin{array}{l}\text { Not possible to } \\
\text { maintain high soil } \\
\text { water potential } \\
\text { throughout the } \\
\text { growing season }\end{array}$ & $\begin{array}{l}\text { Possible to } \\
\text { maintain high soil } \\
\text { water potential } \\
\text { throughout the } \\
\text { growing season } \\
\text { and minimize the } \\
\text { effect of salinity }\end{array}$ \\
\hline $\begin{array}{l}\text { Suitability to } \\
\text { handle brackish } \\
\text { wastewater } \\
\text { without significant } \\
\text { yield loss }\end{array}$ & $\begin{array}{l}\text { Fair to medium. } \\
\text { With good } \\
\text { management } \\
\text { and drainage } \\
\text { acceptable } \\
\text { yields are } \\
\text { possible }\end{array}$ & $\begin{array}{l}\text { Fair to medium. } \\
\text { Good irrigation } \\
\text { and drainage } \\
\text { practices } \\
\text { can produce } \\
\text { acceptable } \\
\text { yields }\end{array}$ & $\begin{array}{l}\text { Poor to fair. Most } \\
\text { crops suffer from } \\
\text { leaf damage and } \\
\text { yield is low }\end{array}$ & $\begin{array}{l}\text { Excellent to } \\
\text { good. Almost } \\
\text { all crops can be } \\
\text { grown with very } \\
\text { little reduction in } \\
\text { yield }\end{array}$ \\
\hline
\end{tabular}

Source: Adapted from Pescod (1992)

angle, and position on plant; type and concentration of salt; ambient temperature; air velocity; irrigation frequency; and length of time the leaf remains wet (Maas and Grattan, 1999). Since the problem is related more to the frequency than the duration of sprinkler irrigation, infrequent and heavy irrigations should be preferred over frequent and light irrigations (Qadir and Minhas, 2008). Several parameters for the evaluation of commonly used irrigation methods in relation to risk reduction are given in Table 11.6.

\section{Irrigation, drainage, and root-zone salinity management}

While using saline water or wastewater, the volume of irrigation water applied should be in excess of crop water requirement (evapotranspiration) and predictable 
rainfall should be taken into consideration as it leaches excess salts from the root zone. Salinity control by effective leaching of the root zone therefore becomes an important option for farmers who do not have limited water allocations. In order to calculate leaching requirement, farmers will need assistance to analyse the electrical conductivity of their soils and irrigation water so that the following equation can be used.

$$
\mathrm{LR}=\mathrm{EC}_{w} /\left[5\left(\mathrm{EC}_{e}\right)-\left(\mathrm{EC}_{w}\right)\right]
$$

LR refers to leaching requirement (additional water fraction of the irrigation water) needed to control salts in the root zone within the salt tolerance level of a specific crop with the routine surface irrigation method, i.e. the fraction of infiltrated water that must pass through the root zone to keep soil salinity within a specific level. $\mathrm{EC}_{w}$ is electrical conductivity of applied irrigation water expressed in terms of $\mathrm{dS}$ $\mathrm{m}^{-1}$. EC $\mathrm{E}_{e}$ refers to the average soil salinity (determined from the extract of saturated soil paste; also expressed as $\mathrm{dS} \mathrm{m}^{-1}$ ) in the root zone that can be tolerated by the crop under consideration. The values given in Table 11.5 for different crops can be used. These values also provide information on yield loss by these crops as the salinity of the growth medium increases.

The LR is needed to calculate the total water requirement (AW) of the crop. This can be estimated from Equation 11.2 (Ayers and Westcot, 1985).

$$
\mathrm{AW}=\mathrm{ET} /(1-\mathrm{LR})
$$

AW refers to the depth of applied water per unit area on a yearly or seasonal basis $\left(\mathrm{mm} \mathrm{yr}^{-1}\right)$; ET is the annual or seasonal crop water consumption expressed as evapotranspiration $\left(\mathrm{mm} \mathrm{yr}^{-1}\right)$; and $\mathrm{LR}$ is the leaching requirement expressed as a fraction (see above). Both AW and ET can also be expressed in terms of $\mathrm{m}^{3}$ of water $\left(1 \mathrm{~mm}=10 \mathrm{~m}^{3} \mathrm{ha}^{-1}\right)$.

The leaching required to maintain salt balance in the root zone may be achieved either by applying sufficient water at each irrigation to meet the LR or by applying, less frequently, a leaching irrigation sufficient to remove the salts accumulated from previous irrigations. The leaching frequency depends on the salinity status in water or soil, salt tolerance of the crop and climatic conditions (Qadir and Minhas, 2008). The amount of rainfall should be taken into consideration while estimating the leaching requirement and selecting the leaching method. Although leaching is essential to prevent root-zone salinity, leaching under saline wastewater irrigation may result in the movement of nitrates, metals, metalloids and salts to the groundwater. Therefore, monitoring of groundwater levels and quality is an essential indicator of environmental performance (Lazarova and Bahri, 2005).

Adequate soil drainage is considered to be an essential prerequisite to achieving leaching requirement vis-à-vis salinity control in the root zone. Natural internal drainage alone may be adequate if there is sufficient storage capacity in the soil 
profile or a permeable subsurface layer occurs that drains to a suitable outlet. An artificial system must be provided if such natural drainage is not present. Otherwise the resultant root-zone salinity control will not be sustainable. Besides, adequate soil drainage, land-levelling and adequate depth of groundwater are also basic components to maintain salinity in the root zone at a specific level. The suitable depth of groundwater depends on climate, groundwater quality and $\operatorname{crop}(s)$ to be grown.

\section{Conjunctive use with freshwater}

Saline wastewater can be used for irrigation in conjunction with freshwater, if available, through cyclic and blending approaches. Several studies have evaluated different aspects of these approaches on a field scale (Oster, 1994; Qadir and Oster, 2004; Rhoades, 1989; Sharma and Rao, 1998; Shennan et al., 1995). These approaches allow a good degree of flexibility to fit into different situations. Guidelines pertaining to water quality for irrigation in terms of salinity- and sodicity-related parameters were mentioned in Chapters 2 and 6 in this volume.

The cyclic strategy involves the use of saline wastewater and non-saline irrigation water in crop rotations that include both moderately salt-sensitive and salt-tolerant crops. Typically, the non-saline water is also used before planting and during initial growth stages of the salt-tolerant crop while saline water is usually used after seedling establishment (Oster, 1994; Rhoades, 1989). The cyclic strategy requires a crop-rotation plan that can make best use of the available good-quality water and saline wastewater, and takes into account the different salt sensitivities among the crops grown in the region, including the changes in salt sensitivities of crops at different stages of growth. The advantages of the cyclic strategy include:

- Steady-state salinity conditions in the soil profile are never reached because the quality of irrigation water changes over time.

- Soil salinity is kept lower over time, especially in the topsoil during seedling establishment.

- A broad range of crops, including those with high economic-value and moderate salt sensitivity, can be grown in rotation with salt-tolerant crops.

- Conventional irrigation systems can be used.

Studies addressing the cyclic use of drainage waters (Oster, 1994; Rhoades, 1989; Shennan et al., 1995) have shown that this strategy is sustainable for cotton, wheat, safflower (Carthamus tinctorius L.), sugar beet, tomato (Lycopersicon esculentum Mill.), cantaloupe (Cucumis melo L.) and pistachio (Pistacia vera L.), provided that the problems of crusting or poor aeration are dealt with through optimum management. Sharma and Rao (1998) provided further evidence from a study area where waters with various levels of salinity $\left(\mathrm{EC}=6,9,12,18.8 \mathrm{dS} \mathrm{m} \mathrm{m}^{-1}\right)$ were 
used successfully for seven years to irrigate different crops like wheat, pearl millet (Pennisetum glaucum (L.) R. Br.) and sorghum with acceptable yield reductions but without any serious degradation of a coarse-textured soil. The soil salinity levels were managed satisfactorily by monsoon rains and in part pre-sowing irrigation of $70 \mathrm{~mm}$ with low-salinity canal water. However, the extent of salt leaching was heavily dependent on the total amount of monsoon rainfall and subsurface drainage.

Blending consists of mixing good- and poor-quality water supplies before or during irrigation. Saline wastewater can be pumped directly into the nearest irrigation canal or water channel. The quantity of saline wastewater pumped into the canal can be regulated so that target salinities in the blended water can be achieved (Oster, 1994; Rhoades, 1989). Water qualities are altered, according to the availability of different irrigation water qualities and quantities, between or within an irrigation event. Blending saline waters with good-quality irrigation waters has been a common practice in several countries such as India, Pakistan and the USA (Minhas, 1996; Qadir and Oster, 2004).

\section{Seedbed preparation and planting techniques}

Since most crops are salt-sensitive at germination stage, it is important to avoid the use of saline wastewater at this critical time. Under field conditions, it is possible, by modifications of planting practices, to minimize salt-accumulation around the seed and to improve the standing of crops that are sensitive to salts during germination. These modifications can include sowing near the bottom of the furrows on both sides of the ridges, raising seedlings with freshwater and their transplanting, using mulches to carry over soil moisture for longer period and increasing the seed or seedling rate per unit area (plant density) to compensate for possible decrease in germination and growth (Minhas, 1996; Tanji and Kielen, 2002).

\section{Soil and water treatment}

Irrigation with sodic wastewater needs provision of a source of $\mathrm{Ca}^{2+}$ to mitigate $\mathrm{Na}^{+}$ effects on soils and crops. Gypsum $\left(\mathrm{CaSO}_{4} \cdot 2 \mathrm{H}_{2} \mathrm{O}\right)$ is the most commonly used source of $\mathrm{Ca}^{2+}$; its requirement for sodic water depends on the $\mathrm{Na}^{+}$concentration and can be estimated through simple analytical tests. Gypsum can be added to the soil, applied with irrigation water by using gypsum beds or placing gypsum stones in water channels. In the case of calcareous soils containing precipitated or native calcite $\left(\mathrm{CaCO}_{3}\right)$, none or a much lower rate of gypsum application may work well. Plant residues and other organic matter left in or added to the field can also improve the chemical and physical conditions of soils irrigated with sodic wastewater. In addition, biological treatment of salt-prone wastewater by standard 
activated sludge culture can be triggered by the inclusion of salt-tolerant organisms to improve treatment efficiency.

Where available, high-electrolyte waters containing an adequate proportion of divalent cations such as $\mathrm{Ca}^{2+}$ can be used for sodic and saline-sodic soil amelioration. These waters can improve soil hydraulic properties without the need to apply a calcium-supplying amendment (Qadir et al., 2007a; Quirk, 2001). However, the ratio of divalent cations, particularly $\mathrm{Ca}^{2+}$, to total cations (TC) in the applied water should be at least 0.3 . Synthesis of the data on total cationic and $\mathrm{Ca}^{2+}$ concentrations in several wastewater samples suggests that wastewaters have a wide range of calcium to TC ratio $\left(C_{\mathrm{Ca}}: C_{\mathrm{TC}}\right)$, i.e. from as low as 0.03 to as high as 0.80 (Table 11.7). These contrasting observations reveal that the use of wastewater to irrigate sodic soils should be carefully planned as the $C_{\mathrm{Ca}}: C_{\mathrm{TC}}$ should be over the threshold value of 0.3 . Several studies have demonstrated that adequate amounts of $\mathrm{Ca}^{2+}$ supplied through irrigation water or applied to the soil in the form of some amendment improve soil structure and counterbalance the negative effects of high concentrations of $\mathrm{Na}^{+}$when sodic soils are brought under cultivation (Oster et al., 1999; Qadir et al., 2001).

The applicability of the high-electrolyte water is effective under certain conditions:

- The sodic soil under amelioration and management has smectite- and montmorillonite-type clay minerals with low hydraulic conductivity.

- The soil physical condition has deteriorated and hydraulic conductivity is so low that the time required for amelioration or the amount of amendment required is excessive.

- The irrigation water to be used following amelioration is so low in electrolyte concentration that water transmission would decrease adversely.

Table 11.7 Concentrations of total cations ( mmol $_{c}$ per litre) and calcium ( mmol $_{c}$ per litre), and ratio of calcium to total cations in wastewater samples

\begin{tabular}{cccl}
\hline Total cations $\left(C_{\mathrm{TC}}\right)^{a}$ & Calcium $\left(C_{\mathrm{Ca}}\right)$ & $C_{\mathrm{Ca}}: C_{\mathrm{TC}}$ & Reference \\
\hline 7.0 & 1.6 & 0.23 & Kaul et al. (2002) \\
10.0 & 2.7 & 0.27 & Kaul et al. (2002) \\
17.0 & 3.7 & 0.22 & Mitra and Gupta (1999) \\
19.0 & 5.0 & 0.26 & Mitra and Gupta (1999) \\
8.0 & 2.5 & 0.31 & Arora et al. (1985) \\
9.0 & 2.8 & 0.31 & Baddesha et al. (1986) \\
9.0 & 7.2 & 0.80 & CSSRI (2004) \\
21.0 & 11.0 & 0.52 & CSSRI (2004) \\
44.0 & 1.5 & 0.03 & Ensink et al. (2002) \\
\hline
\end{tabular}

${ }^{\mathrm{a}} C_{\mathrm{TC}} \approx \mathrm{EC}\left(\mathrm{dS} \mathrm{m}^{-1}\right) \times 10$. 


\section{ORGANIC CONTAMINANTS}

Exposure of consumers, farmers and crops in developing countries to organic contaminants is probably much higher through direct pesticide application than via contaminated irrigation water. The challenge of any related risk (and its mitigation) starts with its assessment, which is costly if based on actual analysis (see Chapter 6). A possible alternative for pesticides is to predict the risk based on easier to measure environmental factors and application practices, using, for example, the free Pesticide Impact Rating Index (PIRI) software, mentioned in Chapter 6, which was developed in Australia but also been applied elsewhere, like Sri Lanka. More difficult and costly would be the analysis of organic contaminants of emerging concern, like residual pharmaceuticals or endocrine disruptor compounds. This limits the current knowledge on their actual risk in wastewater irrigation, which has so far been ranked as relatively low compared, for example, to pathogenic hazards (Chang et al., 2002; Toze, 2006b; WHO, 2006b).

To address organic contaminants preventive measures are therefore more suitable than any soil or water treatment. Key activities include the use of alternative pesticides or integrated pest management. In order to avoid pesticides entering streams used for irrigation or other purposes, buffer zones, run-off reduction and the use of wetlands for remediation could be considered. Containment of contaminated water in dams or wetlands may provide time for pesticides to be removed by sediments or through degradation. Farming practices that reduce run-off, such as the provision of vegetation cover or vegetated bufferstrips (Box 11.3), can significantly reduce the probability of environmental impacts (Finlayson and Silburn, 1996; Kennedy, 1999; USDA, 2000). In spiking trials, the FILTER system has also been shown to reduce pesticide loads by more than 98 per cent (Biswas et al., 2000).

The key removal mechanisms for most organic substances are adsorption and biodegradation in soils and sediments (WHO, 2006b). Removal efficiencies are greater in soils rich in silt, clay and organic matter. Black carbon, in particular, can play a significant role in fixing highly toxic polycyclic aromatic hydrocarbons, polychlorinated biphenyls, dioxins, polybrominated diphenylethers and pesticides (Koelmans et al., 2006).

Chemical stability and slow natural attenuation of certain POPs, such as polychlorinated biphenyls (PCBs) and 1,1,1-trichloro-2,2-bis(4-chlorophenyl) ethane (DDT), make remediation of these compounds a particularly intractable environmental challenge. The approach usually taken is to isolate affected sites and either remove the contaminated soil or rely on phytoremediation as described above. 


\section{BOX 11.3 BUFFER-STRIPS}

There is a dearth of empirical evidence on the performance of various options for mitigating diffuse pollution from agriculture. Especially, riparian buffers have received significant attention over the past 20 years. Ranges for positive buffer efficacy were found to be 30-100 per cent for soil sediment, 30-95 per cent for total phosphorus, 10-100 per cent for total nitrogen, 30-100 per cent for pesticides and 53-100 per cent for faecal indicator organisms. Since many of the experiments underpinning these data were conducted under 'ideal' operating conditions, it is likely that buffer performance in nature will be lower. Overall, the evidence base suggests that buffers provide at least useful short-term benefits, while longer-term impacts remain questionable owing to risks of pollution swapping (Collins et al., 2009).

\section{Conclusions}

There is a variety of management options for smallholder farmers in developing countries to address the challenges and risks of exposure to heavy metals or excessive salts and nutrients through irrigation water. These measures include soil- and water-based interventions as well as changes in crops and crop varieties. Currently available techniques that have been successfully applied to remediate metal or metalloid contaminated soils include in situ and ex situ engineering options, irrigation management options, in situ soil-based immobilization, phytoremediation, chelate-enhanced phytoextraction, etc. In certain cases, farmers and authorities might have no other choice than to cultivate better adapted and non-edible crops, or to zone the areas for non-agricultural land use. In view of possible organic contaminants, appropriate pest and pesticide management will remain more important than soil and water treatment. All methods have however also their drawbacks in effectiveness, duration and economics (Iskandar and Adriano, 1997; Zaurov et al., 1999). Due to the additional risk of bioaccumulation it is in many cases not possible to provide details on the general effectiveness of measures in terms of health-risk reduction, which will largely depend on a variety of site conditions, as well as spatial and temporal factors. While our knowledge is much advanced in view of challenges related to excess nutrients and salts, large gaps remain for heavy metals and, in particular, organic contaminants. A key constraint to risk assessments and mitigation is the missing capacity to analyse and monitor these constituents, especially in developing countries. It remains, therefore, crucial to support pollution preventing policies and measures, including the reduction of possible fertilizer subsidies where they have led to over-fertilization. In the case of metals, metalloids, nutrients and emerging contaminants, pre-treatment and/or segregation of industrial wastewater from the domestic and municipal wastewater stream (eventually used for irrigation) should have highest priority 
(Patwardhan, 2008). Also, the sources of salts in wastewater can be reduced by using technologies in the industrial sector that reduce salt consumption vis-à-vis discharge into the sewage system. In addition, many hazardous chemicals can be replaced in production processes and restrictions can be imposed on the use of certain products for domestic use that are major sources of, for example, salts in wastewater (Lazarova and Bahri, 2005).

\section{REFERENCES}

Abaidoo, R. C., Keraita, B., Drechsel, P., Dissanayake, P. and Maxwell, A. X. (2009) 'Soil and crop contamination through wastewater irrigation and options for risk reduction in developing countries', in P. Dion (ed) Soil Biology and Agriculture in the Tropics, Springer Verlag, Heidelberg (in press)

Abou-Shanab, R. A., Angle, J. S., Delorme, T. A., Chaney, R. L., Van Berkum, P., Moawad, H., Ghanem, K. and Ghozlan, H. A. (2003) 'Phizobacterial effects on nickel extraction from soil and uptake by Alyssum murale', New Phytologist, vol 158, pp219-24

Abramovitch, R. A., ChangQing, L., Hicks, E. and Sinard, J. (2003) 'In situ remediation of soils contaminated with toxic metal ions using microwave energy', Chemosphere, vol 53, pp1077-85

Alvarez-Ayuso, E. and García-Sánchez, A. (2003) 'Sepiolite as a feasible soil additive for the immobilization of cadmium and zinc', Science of the Total Environment, vol 305, nos 1-3, pp1-12

Anderson, C. W. N., Brooks, R. R., Chiarucci, A., LaCoste, C. J., Leblanc, M., Robinson, B. H., Simcock, R. and Stewart, R. B. (1999) 'Phytomining for nickel, thallium and gold', Journal of Geochemical Exploration, vol 67, pp407-15

Arora, B. R., Azad, A. S., Singh, B. and Shekon, G. S. (1985) 'Pollution potential of municipal wastewater of Ludhina, Punjab', Indian Journal of Ecology, vol 12, pp1-7

Awuah, E., Oppong-Peprah, M., Lubberding, H. J. and Gijzen., H. J. (2004) 'Comparative performance studies of water lettuce, duckweed, and algal-based stabilization ponds using low-strength sewage', Journal of Toxicology and Environmental Health, vol 67, pp1727-39

Ayers R. S. and Westcot, D. W. (1985) Water Quality for Agriculture, Irrigation and Drainage, Paper 29, Rev 1, FAO, Rome

Baddesha, H. S., Rao, D. L. N., Abrol, I. P. and Chhabra, R. (1986) Indian Journal of Agricultural Sciences, vol 56, pp584-91

Baker, A. J. M. and Whiting, S. N. (2002) 'In search of the holy grail - A further step in understanding metal hyperaccumulation', New Phytologist, vol 155, pp1-7

Basta, N. T., Gradwohl, R., Snethen, K. L. and Schroder, J. L. (2001) 'Chemical immobilization of lead, zinc and cadmium in smelter-contaminated soils using biosolids and rock phosphate', Journal of Environmental Quality, vol 30, no 4, pp1222-30

Bellows, A. C. (1999) 'Urban food, health, and the environment: The case of Upper Silesia, Poland', in M. Koc, R. MacRae, L. J. A. Mougeot and J. Welsh (eds) For Hunger-Proof Cities: Sustainable Urban Food Systems, International Development Research Centre, Ottawa, pp131-5 
Biswas, T. K., Naismith, A. N. and Jayawardane, N. S. (2000) 'Performance of a land FILTER technique for pesticide removal from contaminated water', in J. A. Adams and A. K. Metherell (eds) Soil 2000: New Horizons for a New Century, Lincoln University, Christchurch Canterbury, New Zealand, pp23-4

Blackwell, J. and Arakel, A. (2004) 'Can integration of sequential biological concentration and the SAL-PROCTM processes result in sustainable management of irrigation drainage?', Desalination Conference, October 2004, El Paso, TX, www.geo-processors. com/files/Geo_InternationalSalinityForum05.pdf

Blumenthal, U. J., Peasey, A., Ruiz-Palacios, G. and Mara, D. D. (2000) Guidelines for Wastewater Reuse in Agriculture and Aquaculture: Recommended Revisions Based on New Research Evidence, Task No 68, Part 1, WELL Study, London School of Hygiene and Tropical Medicine, London / Loughborough University, Loughborough

Bolan, N. S., Adriano, D. C., Natesan, R. and Koo, B.-J. (2003) 'Effects of organic amendments on the reduction and phytoavailability of chromate in mineral soil', Journal of Environmental Quality, vol 32, pp120-28

Branquinho, C., Serrano, H. C., Pinto, M. J. and Martins-Loução, M. A. (2007) 'Revisiting the plant hyperaccumulation criteria to rare plants and earth abundant elements', Environmental Pollution, vol 146, pp437-43

Brooks, R. R. (1977) 'Copper and cobalt uptake by Haumaniastrum species', Plant Soil, no 48, pp541-4

Brooks, R. R., Morrison, R. S., Reeves, R. D. and Malaisse, F. (1978) 'Copper and cobalt in African species of Aeolanthus Mart', Plant Soil, no 50, pp503-7

Brooks, R. R., Trow, J. M., Veillon, J.-M. and Jaffre, T. (1981) 'Studies on manganeseaccumulating Alyxia from New Caledonia', Taxon, vol 30, pp420-23

Brown, S. L., Angle, J. S., Chaney, R. L. and Baker, A. J. M. (1995a) 'Zinc and cadmium uptake by Thlaspi caerulescens and Silene cucubalis grown on sludge-amended soils in relation to total soil metals and soil pH', Environmental Science and Technology, vol 29, pp1581-5

Brown, S. L., Chaney, R. L., Angle, J. S. and Baker, A. J. M. (1994) 'Zinc and cadmium uptake by Thlaspi caerulescens and Silene cucubalis in relation to soil metals and soil $\mathrm{pH}$ ', Journal of Environmental Quality, vol 23, pp1151-7

Brown, S. L., Chaney, R. L., Angle, J. S. and Baker, A. J. M. (1995b) 'Zn and Cd uptake of Thlaspi caerulescens grown in nutrient solution', Soil Science Society of America Journal, vol 59, pp125-133

Brown, S. L., Chaney, R., Hallfrisch, J., Ryan, J. A. and Berti, W. R. (2004) 'In situ soil treatments to reduce the phyto- and bio-availability of lead, zinc and cadmium', Journal of Environmental Quality, vol 33, pp522-31

Central Soil Salinity Research Institute (2004) 'Use of urban and industrial effluent in agriculture', Annual Progress Reports (2000-2003), NATP-MM Project (CSSRI), Karnal, India

Chaney, R. L., Angle, J. S., Broadhurst, C. L., Peters, C. A., Tappero, R. V. and Sparks, D. L. (2007) 'Improved understanding of hyperaccumulation yields commercial phytoextraction and phytomining technologies', Journal of Environmental Quality, vol 36, pp1429-43

Chang, A. C., Pan, G., Page, A. L. and Asano, T. (2002) 'Developing human health-related chemical guidelines for reclaimed water and sewage sludge applications in agriculture', 
report for WHO, www.who.int/water_sanitation_health/wastewater/gwwuchemicals. pdf

Chen, M., Ma, L. Q., Singh, S. P., Cao, R. X. and Melamed, R. (2003) 'Field demonstration of in situ immobilization of soil $\mathrm{Pb}$ using $\mathrm{P}$ amendments', Advances in Environmental Research, vol 8, pp 93-102

Chen, Y., Shen, Z., Li, X. (2004) 'The use of vetiver grass (Vetiveria zizanioides) in the phytoremediation of soils contaminated with heavy metals', Applied Geochemistry, vol 19, pp1553-65

Chlopecka, A. and Adriano, D. C. (1997) 'Influence of zeolite, apatite and Fe-oxide on $\mathrm{Cd}$ and Pb uptake by crops', Science of the Total Environment, vol 207, nos 2-3, pp195-206

Clemens, S. (2001) 'Molecular mechanisms of plant metal tolerance and homeostasis', Planta, vol 212, pp475-86

Cobbett, C. (2003) 'Heavy metals and plants - Model system and hyperaccumulators', New Phytologist, vol 159, pp289-93

Collins, A. L. Hughes, G., Zhang, Y. and Whitehead, J. (2009), 'Mitigating diffuse water pollution from agriculture: Riparian buffer strip performance with width', $C A B$ Reviews: Perspectives in Agriculture, Veterinary Science, Nutrition and Natural Resources, vol 4, no 39, p15

Cunningham, S. D., Berti, W. R. and Huang, J. W. (1995) 'Phytoremediation of contaminated soils', Trends in Biotechnology, vol 13, pp393-7

Derem, A., Denayer, F. O., Petit, D. and Haluwyn, C. V. (2006) 'Seasonal variations of cadmium and zinc in Arrhenatherum elatius, a perennial grass species from highly contaminated soils', Environmental Pollution, vol 140, pp62-70

Dutré, V., Kestens, C., Scaep, J. and Vandecasteele, C. (1998) 'Study of the remediation of a site contaminated with arsenic', Science of the Total Environment, vol 220, nos 2-3, pp185-94

Duxbury, J. M., Panaullah, G. and Koo-Oshima, S. (2007) Remediation of Arsenic for Agriculture, Sustainability, Food Security and Health in Bangladesh, FAO Water Working Paper, FAO, Rome

Ensink, J. H. J., van der Hoek, W., Matsuno, Y., Munir, S. and Aslam, M. R. (2002) Use of Untreated Wastewater in Peri-urban Agriculture in Pakistan: Risks and Opportunities, Research Report 64, International Water Management Institute (IWMI), Colombo, p22

Finlayson, B. and Silburn, M. (1996) 'Soil, nutrient and pesticide movements from different land use practices, and subsequent transport by rivers and streams', in H. M. Hunter, A. G. Eyles and G. E. Rayment (eds) Downstream Effects of Land Use, Department of Natural Resources, Queensland, pp9-14

Francesconi, K., Visoothiviseth, P., Sridokchan, W. and Goessler, W. (2002) 'Arsenic species in an arsenic hyperaccumulating fern Pityrogramma calomelanos: A potential phytoremediator of arsenic-contaminated soils', Science of the Total Environment, vol 284, nos 1-3, pp27-35

García-Sánchez, A., Alastuey, A. and Querol, X. (1999) 'Heavy metal adsorption by different minerals: Application to the remediation of polluted soils', Science of the Total Environment, vol 242, nos 1-3, pp179-88 
Gardner, E. A., Morton, D., Sands, J., Mathews, P., Cook, F. J. and Jayawardane, N. S. (2001) 'The FILTER system for tertiary treatment of sewage effluent by land application - its performance in a subtropical environment', Water Science and Technology, vol 10, pp335-42

Goethberg, A., Greger, M. and Bengtsson, B. E. (2002) 'Accumulation of heavy metals in water spinach (Ipomea aquatica) cultivated in the Bangkok region, Thailand', Environmental Toxicology and Chemistry, vol 21, no 9, pp1934-9

González, R. C. and González-Chávez, M. C. A. (2006) 'Metal accumulation in wild plants surrounding mining wastes', Environmental Pollution, vol 144, pp84-92

Greman, H., Vodnik, D., Velinkonja-Bolta, S. and Lestan, D. (2003) 'Ethylenediaminedissuccinate as a new chelate for environmentally safe enhanced lead phytoextraction', Journal of Environmental Quality, vol 32, pp500-506

Haidouti, C. (1997) 'Inactivation of mercury in contaminated soils using natural zeolites', Science of the Total Environment, vol 208, nos 1-2, pp105-9

Hamilton, A. J., Boland, A.-M., Stevens, D., Kelly, J., Radcliffe, J., Ziehrl, A., Dillon, P. J. and Paulin, R. (2005) 'Position of the Australian horticultural industry with respect to the use of reclaimed water', Agricutural Water Management, vol 71, pp181-209

Hamilton, A. J., Stagnitti, F., Xiong, X., Kreidl, S. L, Benke, K. K. and Maher, P. (2007) 'Wastewater irrigation: The state of play', Vadose Zone Journal, vol 6, no 4, pp823-40

Hettiarachchi, G. M. and Pierzynski, G. M. (2002) 'In situ stabilization of soil Pb using phosphorous and manganese oxide', Journal of Environmental Quality, vol 31, pp56472

Hettiarachchi, G. M., Pierzynski, G. M. and Ransom, M. D. (2001) 'In situ stabilization of soil lead using phosphorous', Journal of Environmental Quality, vol 30, pp1214-21

Hussain, S. I. (2000) 'Irrigation of crops with sewage effluent: Implications and movement of lead and chromium as affected by soil texture, lime, gypsum and organic matter', PhD thesis, Department of Soil Science, University of Agriculture, Faisalabad, p190

Iimura, K. (1981) 'Chemical forms and behavior of heavy metals in soils', in K. Kitagishi and I. Yamane (eds) Heavy Metal Pollution in Soils of Japan, Japan Science Society Press, Tokyo, pp27-35

Iskandar, I. K. and Adriano, D. C. (eds) (1997) Remediation of Soils Contaminated with Metals, Advances in Environmental Science, Science Reviews, Northwood, UK

Janssen, B. H., Boesveld, H. and Rodriguez, M. J. (2005) 'Some theoretical considerations on evaluating wastewater as a source of N, P and K for crops', Irrigation and Drainage, vol 54, no S1, ppS35-S47

Jayawardane, N. S. (1995) Wastewater Treatment and Reuse through Irrigation, with Special Reference to the Murray Basin and Adjacent Coastal Areas, Division of Water Resources - Divisional Report, no 95/1, CSIRO, Collingwood, Australia

Jayawardane, N. S., Biswas, T. K., Blackwell, J. and Cook, F. J. (2001) 'Management of salinity and sodicity in a land FILTER system, for treating saline wastewater on a saline-sodic soil', Australian Journal of Soil Research, vol 39, pp1247-58

Jiménez, B. and Asano, T. (2008) 'Water reclamation and reuse around the world', in B. Jiménez and T. Asano (eds) Water Reuse: An International Survey of Current Practice, Issues and Needs, IWA Publishing, London

Johnson, S. (2006) 'Are we at risk from metal contamination in rice?', Rice Today, JulySeptember 2006, p36 
Kaul, S. N., Juwarkar, A. S., Kulkarni, V. S., Nandy, T., Szpyrkowicz, L. and Trivedy, R. K. (2002) Utilization of Wastewater in Agriculture and Aquaculture, Science Publishers, Jodhpur, p675

Kennedy, I. R. (1999) 'Environmental fate and transport of cotton pesticides', in S. A. Hahndorf and P. A. Jones (eds) Proceedings 1998 Riverine Environment Forum, MurrayDarling Basin Commission, Canberra, pp51-60

Kersten, W. J., Brooks, R. R., Reeves, R. D. and Jaffre, T. (1979) 'Nickel uptake by New Caledonian species of Phyllanthus', Taxon, vol 28, pp529-34

Kobayashi, E., Okudo, Y., Suwazono, Y., Kido, T., Nishijo, M., Nakagawa, H. and Nogawa, K. (2002) 'Association between total cadmium intake calculated from the cadmium concentration in household rice and mortality among inhabitants of the cadmium-polluted Jinzu River basin of Japan', Toxicology Letters, no 129, pp85-91

Koelmans, A. A., Jonker, M. T. O., Cornelissen, G., Bucheli, T. D., VanNoort, P. C. M. and Gustafsson, O. (2006) 'Black carbon: The reverse of its dark side', Chemosphere, vol 63, pp365-77

Kukier, U. and Chaney, R. L., (2001) 'Amelioration of nickel phytotoxicity in muck and mineral soils', Journal of Environmental Quality, vol 30, pp1949-60

Kumar, P. B. A. N., Dushenkov, V., Motto, H. and Raskin, I. (1995) 'Phytoextraction: The use of plants to remove heavy metals from soils', Environmental Science and Technology, vol 29, pp1232-8

Lazarova, V. and Bahri, A. (2005) Water Reuse for Irrigation: Agriculture, Landscapes, and Turf Grass, CRC Press, Boca Raton, FL

Lombi, E., Hamon, R. E., Wieshammer, G., McLaughlin, M. J. and McGrath, S. P. (2004) 'Assessment of the use of industrial byproducts to remediate a copper and arsenic contaminated soil', Journal of Environmental Quality, vol 33, pp902-10

Lombi, E., Zhao, J. J., Dunham, S. J. and McGrath, S. P. (2001) 'Phytoremediation on heavy metal contaminated soils. Natural hyperaccumulation versus chemically enhanced phytoextraction', Journal of Environmental Quality, vol 30, pp1919-26

Maas, E. V. and Grattan, S. R., (1999) 'Crop yields as affected by salinity', in R.W. Skaggs and J. van Schilfgaarde (eds) Agricultural Drainage, ASA-CSSA-SSSA, Madison, WI, pp55-108

Madrid, F., Liphadzi, M. S. and Kirkham, M. B. (2003) 'Heavy metal displacement in chelate-irrigated soil during phytoremediation', Journal of Hydrology, vol 272, pp10719

Mahatantila, K., Chandrajith, R., Jayasena, H. A. H. and Ranawana, K. B. (2008) 'Spatial and temporal changes of hydrogeochemistry in ancient tank cascade systems in Sri Lanka: Evidence for a constructed wetland', Water and Environment Journal, vol 22, pp17-24

Malliou, E., Loizidou, M. and Spyrellis, N. (1994) 'Uptake of lead and cadmium on clinoptilolite', Science of the Total Environment, vol 149, no 3, pp139-44

McGowen, S. L., Basta, N. T. and Brown, G. O. (2001) 'Use of diammonium phosphate to reduce heavy metal solubility and transport in smelter-contaminated soil', Journal of Environmental Quality, vol 30, pp493-500

McLaughlin, M. J. and Singh, B. R. (1999) Cadmium in Soils and Plants, Kluwer Academic Publishers, Dordrecht, The Netherlands, p271 
Meharg, A. A., Lombi, E., Williams, P. N., Scheckel, K. G., Feldmann, J., Raab, A., Zhu, Z. and Islam, I. (2008) 'Speciation and localization of arsenic in white and brown rice grains', Environmental Science and Technology, vol 42, no 4, pp1051-57

Melamed, R., Cao, X., Chen, M. and Ma, L. Q. (2003) 'Field assessment of lead immobilization in a contaminated soil after phosphate application', Science of the Total Environment, vol 305, nos 1-3, pp117-27

Minhas P. S. (1996) 'Saline water management for irrigation in India', Agricultural Water Management, vol 30, pp1-24

Mitra, A. and Gupta, S. K. (1999) 'Effect of Sewage water irrigation on essential plant nutrient and pollutant element status in a vegetable growing area around Calcutta', Indian Journal of Society of Soil Science, no 47, pp99-105

Murtaza, G., Ghafoor, A., Qadir, M., Owens, G., Aziz, M. A., Zia, M. H. and Ullah, S. (2009) 'Disposal and use of sewage on agricultural lands in Pakistan: A review', Pedosphere (in press)

Nhapi, I. (2004) 'Potential for the use of duckweed-based pond systems in Zimbabwe', Water $S A$, vol 30, no 1, p1 15

Nhapi., I., Mawere, M., Veenstra, S. and Gijzen, H. (2002) 'Effluent polishing via pasture irrigation in Harare, Zimbabwe', Water Science and Technology, vol 46, no 9, pp28795

Nordberg, G. (2003) 'Cadmium and human health: A perspective based on recent studie in China', Journal of Trace Elements and Experimental Medicine, vol 16, no 4, pp307319

Oste, L. A., Lexmond, T. M. and van Reimsdijk, W. H., (2002) 'Metal immobilization in soils using synthetic zeolites', Journal of Environmental Quality, vol 31, pp813-21

Oster, J. D. (1994) 'Irrigation with poor quality water', Agricultural Water Management, vol 25, pp271-97

Oster, J. D., Shainberg, I. and Abrol, I. P. (1999) 'Reclamation of salt affected soils', in R.W. Skaggs and J. van Schilfgaarde (eds) Agricultural Drainage, ASA-CSSA-SSSA, Madison, WI, pp659-91

Parker, D. R., Page, A. L. and Thomason, D. N. (1991) 'Salinity and boron tolerances of candidate plants for the removal of selenium from soils', Journal of Environmental Quality, vol 20, pp157-64

Patwardhan, A. D. (2008) Industrial Waste Water Treatment, Prentice Hall of India, New Delhi, p292

Pescod, M. B. (ed) (1992) Wastewater Treatment and Use in Agriculture, Irrigation and Drainage Paper no 47, FAO, Rome

Pettygrove, G. S. and Asano, T. (eds) (1985) Irrigation with Reclaimed Municipal Wastewater - A Guide Manual, Lewis Publishers, Chelsea, MI

Pilon-Smits, E. (2005) 'Phytoremediation', Annual Review of Plant Biology, vol 56, pp1539

Qadir, M., Ghafoor, A. and Murtaza, G. (2000) 'Cadmium concentration in vegetables grown on urban soils irrigated with untreated municipal sewage', Environment, Development and Sustainability, vol 2, pp11-19

Qadir, M. and Minhas, P. S. (2008) 'Wastewater use in agriculture: Saline and sodic waters', in S.W. Trimble (ed) Encyclopedia of Water Science, Taylor \& Francis, New York, pp1307-10 
Qadir, M. and Oster, J. D. (2004) 'Crop and irrigation management strategies for salinesodic soils and waters aimed at environmentally sustainable agriculture', Science of the Total Environment, vol 323, pp1-19

Qadir, M., Schubert, S., Ghafoor, A. and Murtaza, G. (2001) 'Amelioration strategies for sodic soils: A review', Land Degradation and Development, vol 12, pp357-86

Qadir, M., Sharma, B. R., Bruggeman, A., Choukr-Allah, R. and Karajeh, F. (2007a) 'Non-conventional water resources and opportunities for water augmentation to achieve food security in water scarce countries', Agricultural Water Management, vol 87, pp2-22

Qadir, M., Tubeileh, A., Akhtar, J., Labri, A., Minhas, P. S. and Khan, M. A. (2008) 'Productivity enhancement of salt-affected environments through crop diversification', Land Degradation and Development, vol 19, pp429-53

Qadir, M., Wichelns, D., Raschid-Sally, L., Minhas, P. S., Drechsel, P., Bahri, A. and McCornick, P. (2007b) 'Agricultural use of marginal-quality water - Opportunities and challenges', in D. Molden (ed) Water for Food, Water for Life: A Comprehensive Assessment of Water Management in Agriculture, Earthscan, London, pp425-57

Quirk, J. P. (2001) 'The significance of the threshold and turbidity concentrations in relation to sodicity and microstructure', Australian Journal of Soil Research, vol 39, pp1185-217

Rhoades, J. D. (1989) 'Intercepting, isolating and reusing drainage waters for irrigation to conserve water and protect water quality', Agricultural Water Management, vol 16, pp37-52

Robinson, B. H., Brooks, R. R. and Clothier, B. E. (1999) 'Soil amendments affecting nickel and cobalt uptake by Berkheya coddii: Potential use for phytomining and phytoremediation', Annals of Botany, vol 84, pp689-94

Römkens, P., Bouwman, L., Japenga, J. and Draaisma, C. (2001) 'Potentials and drawbacks of chelate-enhanced phytoremediation of soils', Environmental Pollution, vol 116, pp109-21

Salt, D. E., Blaylock, M., Kumar, P. B. A. N., Dushenkov, S., Ensley, B. D., Chet, I. and Raskin, I. (1996) 'Phytoremediation: A novel strategy for the removal of toxic metals from the environment using plants', Biotechnology, vol 13, pp468-74

Schwartz, C., Echevarria, G. and Morel, J. L. (2003) 'Phytoextraction of cadmium with Thlaspi caerulescens', Plant and Soil, vol 249, pp27-35

Sharma, D. P. and Rao, K. V. G. K. (1998) 'Strategy for long term use of saline drainage water for irrigation in semi-arid regions', Soil Tillage Research, vol 48, pp287-95

Shennan, C., Grattan, S. R., May, D. M., Hillhouse, C. J., Schactman, D. P., Wander, M., Roberts, B., Burau, R. G., McNeish, C. and Zelinski, L. (1995) 'Feasibility of cyclic reuse of saline drainage in a tomato-cotton rotation', Journal of Environmental Quality, vol 24, pp476-86

Simmons, R. W., Noble, A. D., Pongsakul, P., Sukreeyapongse, O. and Chinabut, N. (2009) 'Cadmium-hazard mapping using a general linear regression model (Irr-Cad) for rapid risk assessment', Environmental Geochemistry and Health, vol 31, pp71-9

Simmons R.W., Pongsakul, P., Saiyasitpanich, D. and Klinphoklap, S. (2005) 'Elevated levels of cadmium and zinc in paddy soils and elevated levels of cadmium in rice grain downstream of a zinc mineralized area in Thailand: Implications for public health', Environmental Geochemistry and Health, vol 27, pp501-11 
Singh, S. P., Ma, L. Q. and Harris, W. G. (2001) 'Heavy metal interactions with phosphatic clay', Journal of Environmental Quality, vol 30, pp1961-8

Stevens, D. and McLaughlin, M. J. (2006) 'Managing risks to soil and plant health from key metals and metalloids in irrigation waters', in D. Stevens (ed) Growing Crops with Reclaimed Wastewater, CSIRO Publishing, Collingwood, Australia, pp139-46

Strom, P. F. (2006) 'Introduction to phosphorus removal. Invited presentation for Wastewater Treatment Operator's Workshop', 91st Annual Meeting, NJWEA, Atlantic City, NJ

Su, N., Bethune, M., Mann, L. and Heuperman, A. (2005) 'Simulating water and salt movement in tile-drained fields irrigated with saline water under a Serial Biological Concentration management scenario', Agricultural Water Management, vol 78, pp16580

Swaddiwudhipong, W., Limpatanachote, P., Mahasakpan, P., Krintratun, S. and Padungtod, C. (2007) 'Cadmium-exposed population in Mae Sot District, Tak Province: 1 . Prevalence of high urinary cadmium levels in the adults', Journal of the Medical Association of Thailand, vol 90, pp143-8

Tanji, K. and Kielen, N. C. (2002) Agricultural Drainage Water Management in Arid and Semi-arid Areas, Irrigation and Drainage Paper 61, FAO, Rome

Teeyakasem, W., Nishijo, M., Honda, R., Satarug, S., Swaddiwudhipong, W. and Ruangyuttikarn, W. (2007) 'Monitoring of cadmium toxicity in a Thai population with high-level environmental exposure', Toxicology Letters, vol 169, pp185-95

Toze, S. (2006a) 'Reuse of effluent water - Benefits and risks', Agricultural Water Management, vol 80, pp147-59

Toze, S. (2006b) 'Water reuse and health risks - Real vs. perceived', Desalination, vol 187, pp41-51

Tu, C. and Ma, L. Q. (2002) 'Effects of arsenic concentration and forms on arsenic uptake by the hyperaccumulator', Journal of Environmental Quality, vol 31, pp641-7

USDA (2000) Conservation Buffers to Reduce Pesticide Losses, United States Department of Agriculture, Natural Resources Conservation Service, Washington, DC

USEPA (1997) Technology Alternatives for the Remediation of Soils Contaminated with As, $\mathrm{Cd}$, Cr, $\mathrm{Hg}$ and Pb, EPA/540/S-97/500, Office of Emergency and Remedial Response, Washington, DC

Vanthuyne, M. and Maes, A. (2002) 'The removal of heavy metals from contaminated soil by a combination of sulfidisation and floatation', Science of the Total Environment, vol 290, nos 1-3, pp69-80

Virkutyte, J., Sillanpaa, M. and Latostenmaa, P. (2002) 'Elektrokinetic soil remediation - Critical review', Science of the Total Environment, vol 289, pp97-121

Warren, G. P. and Alloway, B. J. (2003) 'Reduction of arsenic uptake by lettuce with ferrous sulphate applied to contaminated soil', Journal of Environmental Quality, vol 32, pp767-72

Warren, G. P., Alloway, B. J., Lepp, N. W., Singh, B., Bochereau, F. J. M. and Penny, C. (2003) 'Field trials to assess the uptake of arsenic by vegetables from contaminated soils and soil remediation with iron oxides', Science of the Total Environment, vol 311, nos 1-3, pp19-33

WHO (2006a) Guidelines for Drinking-Water Quality, Incorporating First Addendum: Volume 1, Recommendations, 3rd ed., WHO, Geneva, www.who.int/water_sanitation_ health/dwq/gdwq0506.pdf 
WHO (2006b) Guidelines for the Safe Use of Wastewater, Excreta and Greywater, Volume 2: Wastewater Use in Agriculture, World Health Organization, Geneva

Williams, P. N., Islam, M. R. , Adomako, E. E., Raab, A., Hossain, S. A., Zhu, Y. G., Feldmann, J. and Meharg, A. A. (2006) 'Increase in rice grain arsenic for regions of Bangladesh irrigating paddies with elevated arsenic in groundwaters', Environmental Science and Technology, vol 40, no 16, pp4903-8

Wong, J. W. C., Wong, W. W. Y., Wei, Z. and Jadadeesan, H. (2004) 'Alkaline biosolids and EDTA for phytoremediation of an acidic loamy soil spiked with cadmium', Science of the Total Environment, vol 324, nos 1-3, pp235-46

Wongkongkatep, J., Fukushi, K., Parkpian, P., DeLaune, R. D. and Jugsujinda, A. (2003) 'Arsenic uptake by native fern species in Thailand: Effect of chelating agents on hyperaccumulation of arsenic by Pityrogramma calomelanos', Journal of Environmental Science and Health, vol 38, no 12, pp2773-84

Wu, L. H., Luo, Y. M., Xing, X. R. and Christie, P. (2004) 'EDTA-enhanced phytoremediation of heavy metal-contaminated soil with Indian mustard and associated potential leaching risk', Agriculture, Ecosystems and Environment, vol 102, pp307-18

Xue, S. G., Chen, Y. X., Reeves, R. D., Baker, A. J. M., Lin, Q. and Fernando, D. R. (2004) 'Manganese uptake and accumulation by the hyperaccumulator plant Phytolacca acinosa Roxb (Phytolaccaceae)', Environmental Pollution, vol 131, pp3939

Zaurov, D. E., Perdomo, P. and Raskin, I., (1999) 'Optimizing soil fertility and pH to maximize cadmium removal by Indian mustard from contaminated soils', Journal of Plant Nutrition, vol 22, pp977-86

Zhang, W., Cai, Y., Tu, C. and Ma, L. Q. (2002) 'Arsenic speciation and distribution in an arsenic hyperaccumulating plant', Science of the Total Environment, vol 300, nos $1-3$, pp 167-77

Zhu, B. and Alva, A. K. (1993) 'Trace metal and cation transport in a sandy soil with various amendments', Soil Science Society of America Journal, vol 57, no 3, pp723-7

Zhu, Y. G., Chen, S. B. and Yang, J. C. (2004) 'Effects of soil amendments on lead uptake by two vegetable crops from a lead-contaminated soil from Anhui, China', Environment International, vol 30, no 3, pp351-6 